\title{
SINTREN ART SHOW : THE ANALYSIS OF THE DECLINING OF HISTORICAL AWARENESS HAPPENING IN THE COASTAL BORDER OF WEST JAVA AND CENTRAL JAVA AND ITS CONTRIBUTION TO THE HISTORY LEARNING
}

\author{
Dadang Supardan ${ }^{1}$
}

\begin{abstract}
The study was based on research concerning the declining of historical awareness in the development of Sintren art that has been increasingly marginalized by the globalization, happening particularly in the coastal border of West Java and Central Java. This study uses a combination of historical-ethnographic methods, and for the data collection techniques the study uses observation, interview, and document study. The research results are as follows: (1) The origin of the words "sinyo" means "youth" and "trennen" means "exercise in Sintren art. There is another word like "sesantrian" which means "students play lais mimic, or debus, ubrug rudat using the magical". This Sintren was first created when the habits of the mothers and their children in the time of waiting for their husbands/fathers to come home from fishing in the sea. Instead of sleeping in the afternoon, it was better for them- the fishermen who just stayed in the house, to initiate this Sintren game. (2) The purpose of this Sintren art show at the first time was just as a habit of some women and their children who were waiting for their husbands/fathers to come home from fishing in the sea, to then, developed into a sacred game including the ceremonies for asking rain during the long drought, and served as a means of entertainment (3) Sintren art stages include (a) preparation phase: including gamelan and clothing design, and (b) staging (Sintren, Bodor and Sinden/ Singer). (4) The philosophical contribution values of the Sintren performing arts to the history education, Sintren is basically appreciated as an identity art, reflecting local delicacy, resignation, rules and norms as well as a leader in the whole performance, (5) Efforts to maintain and develop the Sintren art in other areas, especially in the Kasepuhan Cirebon Palace where annual performances of traditional arts, especially, Sintren from various regions are often performed.
\end{abstract}

Key words: art, sintren, declining, historical awareness, traditional, globalization.

${ }^{1}$ Dadang Supardan, Professor of History Education, Faculty of Social Science Education, Indonesia University of Education. For academic interest, the author can be contacted at email: dangsu57@yahoo. com. 


\section{Introduction}

Sintren performing art, sometimes called "Sinden Buyung" who had lived in and triumphed pantura (the border of northerncoastal region), thathadultimately confronted the two sides of reality. The first reality consisted of the daily world of the Sintren actress herself, who was generally born from poor family that was contrastly different with the socio-economical condition from urban society. Poverty had caught her in helplessness in freeding the burdened of her family. Meanwhile, the second reality consisted of supranatural space and time that had to be inherently comprehended by the Sintren dancer. The dancer is usually still considered very young ("gadis bau kencur" or "gadis ingusan"). Her body is covered by multiple layers of clothing, then she is tightly tied with rope wrapped around her entire body, as it is often found in high level magic attraction, after which, she is then put into a chicken cage (Yudistira, 2007: 137)

Few moments later, the handler (Punduh) begins reciting magical incantations, to behold as if a small child approaches "The Sintren". He will soon permeate into the Sintren body, and then enter into her body like a real little kid playing with doll. The audience clapp and cheer with joy watching Sintren who suddenly appears in a dress of a dancer, exudes an aura of beauty that make men flash their eyes by the slim waist and full of charm. "The Sintren" is meandering, until it comes time to collect saweran (money given heartfully to the dancer from the people who watch). Though, it did not actually the Sintren go everywhere, but she just still sits quietly in a cage, even tapering fingers are also seen swinging-swinging swaying with the rhythm of bamboo tube and pitcher (Yudhisthira, 2007: 138-139) and at present, drum and other gamelans have mostly been modified.

The metaphysical event when the Sintren is in what can be termed as one of the holes of multiprospects of excavation results of traditional anonymous mystical art performances in developing and offering new reality. However, "silent" power performance, the Sintren voice that becomes supernatural experience and also the supernatural Sintren experience is truly beautiful and real. As real event, when the little girl is forced to dance without declining the power. As real unweary poverty meanness that is countinously grasped in her family. This unhappiness also makes the Sintren offender at the helpless shadows, and just waiting for the saweran (Hadisastro, 1999:31).

The Sintren world, in addition to the entertainment world, is also the unseen, alien and invisible world, just like pesugihan world (mystical way to be rich) that should always require victims. Surely the first casualty is of the dancer herself (the Sintren). Why? Since becoming the Sintren dancer, she should gracefully accept the reality of the possession in every appearance and she also has to resign herself to the "destiny". The absurdly beautiful Sintren, but abstinence touched by the man because the mystical world only wants Sintren perpetual virginity, a man-no-where is ever allowed to touch her body. Further victim of course the men intoxicated and infatuated to marry the Sintren. However, the Sintren has already dropped the option; she would not be able to escape from the unseen confinement, it is impossible for her to stop being a Sintren dancer. The Sintren is ready to bear all the 
consequences of her choice, with the belief that who jumps who falls. Up until this point, the invisible reality has transformed into the real world, while in daily life, her friends in the village are felt unreal, just like a fiction.

Behavior tells in the Sintren song is not too impressive, but flat and earthy, and not arrogantly mock forms of behavior as other village girls. The singing plot and dancing are not dynamic, predictable, and does not vary like the today song and dance. But, its simplicity of this traditional privilege has been raised to be a charming presence. Understanding Sintren does at least require a high level of appreciation and sensitivity, such as missing childhood memories in the village that is so exciting because of its simplicity and its innocence.

Sintren art that previously was an artistic tradition rooted in the faith of the noble values believed in the north coast at the border of West Java and Central Java (Indramayu, Cirebon, and Brebes) has its uniqueness, its beauty, as well as its oddities, and it also is filled with magic. The uniqueness of Sintren performing arts can be seen from a typical set of gamelan or musical instruments made from pottery named gembyung and the bamboo which is beaten in some typical noisy way. Bamboo gamelan sounds knock a segment called tube or lodong and it is dropped to the ground, inviting natural but unique sound. While traditional song sung with a simple tone strands together and really gives the feel of an ordinary, that make people who love this art show feel its uniqueness and make them miss the sounds at all time (Hadisastro, 1999: 4-5).

The beauty of Sintren art is glowing when a naive and simple country girl, having entered the cage with both hands tied, suddenly turns into a beautiful dancer, a prettier girl, and very much different from the original appearance, especially when she is supported by sunglasses, like a model who is showing off her skill. Other oddities and magical uniqueness of the Sintren performing arts is seen when she is tightly tied and then entered the confinement, and she dresses up like a jolly today girl who is always ready to dance. Meanwhile, the scent smell and pungent aroma of incense that accompanies the mystic singing, featuring thick shades and magical power art (Yudhisthira, 2007: 2527).

The wealth of traditional art that should be preserved until now is among the richness of the Indonesian nation heritages that should be proud of. Sustainability of the human reasoning glory is intended to honor and respect the history of their existence. Sintren art is no exception. Sintren, in various versions, is an art that combines dance and theatrical skills and spiced with acrobatic, even its skillfulness art has even influenced many artists and Sintren performers to develop it further through incorporating elements of magic in it. Thus, if we borrow the H.G. Quartrich Wales term in his book The Making of Greater India: A Study in South-East Asia Culture Change (1948: 3-4). Sintren can be categorized as Local Genius. Where the understanding of local genius in its entirety covers and is identical to Cultural Identity, which is defined as the identity or personality of the culture of Indonesia (Soebadio, 1986: 1819). The characteristics and nature of the local genius have basically: first, the ability to withstand from foreign cultures; second, the ability to accommodate the elements of foreign cultures; Third, the ability to integrate the elements of foreign culture 
into the native culture; fourth, the ability to control, and fifth, the ability to provide direction on the development of culture (Mundardjito, 1986: 40).

Sintren Art which has been born and developed in many coastal areas of the border of Central Java and West Java is often fascinating and intriguing the audience because of its uniqueness in displaying their magical acts. It is said that, a Sintren dancer should be a virgin or a girl. It is intended as a mystical belief that her purity can attract the angel spirit to trance in the body, where in practice, in the presentation of Sintren art, it is always supported by handler Kemlandang or Lais of guardian angel spirit. There are some various versions of the Sintren story, one of the most widely believed by coastal communities is the adaptation from a love story between Sulasih Sulandono, but the love was not accepted by Sulandono's father. Sulandono was from a royal palace family, then by the help of his mother through his powerful magic, the couple could meet each other. Although the couple were deadly in love and they could not physically meet each other, but in the invisible realm world through the help of the dancers they could spiritually meet each other.

As we know that each art represents a typical expression of community represented and occupied at a particular area or region. Through its changing times, its existence needs serious concern, because of the lack appreciation to the existence of traditional arts in the community as well as the reduction of supports from the artists involved. The presence of Sintren traditional art, from day to day, is being abandoned by the society, and felt no longer appropriate to the current development of the times and is not adequate the modern taste (Sedyawati, 1986: 187-188). It would be disastrous, if people no longer care about the development of this traditional arts, because the next generation certainly would not recognise the art because it is no longer exist.

Today, Sintren traditional art, in particular, has shifted its function because of the result of the dynamic life that also demands a change. This change is in line with either the changing times or the mindset of the people. This change has also led to a shift in the appraisal of the reality in its field through the emerging of views on traditional arts in particular. Most rural communities also begin to shift their tastes to the art considered modern (as Solo Organ instrument, Dangdut, Band, Theatres, and soap opera). Conservation and development of traditional art, especially in this era of modernization faced increasing challenge in this powerful era. In fact, the coaching in the traditional art is too late to be implemented, so that many traditional arts are left behind by the communities. There is a trend that traditional arts then be one by one or as a whole will step down from the stage of culture. Although efforts have been made to preserve these traditional arts through records, research and re-staged performances, but still, many types of traditional art is hopeless to be existent.

The wealth of traditional art, preserved this day, as one of the wealth of the nation of Indonesia. To keep it exist and sustainable, honor and respect the history of their existence should be developed through the glory of human reasoning. Sintren art in this case is no exception. Sintren, in various versions of an art, combines dance and theatrical skills and spiced with acrobatic, 
or trick skill, even this art has influenced many Sintren artists and performers to develop further by incorporating elements of magic in it (Hadisastro, 1999: 35). The existence of Sintren arts tradition stems from the belief of the local people towards the noble values of our ancestors, or even could be originated from the custom or ordinary folk games which became a noble tradition. Maybe, the people who used to live in coastal areas would not have thought that the tradition now becomes something rare, which is called culture.

Sintren is a long tradition of coastal people of the North Coast of West Java and Central Java, precisely in Indramayu, Cirebon, and Brebes in particular. Art has now become a rare performance even in the Sintren birth origin areas itself, because its development can only be enjoyed once a year during sea ceremonies or celebration or a celebration of the rich. Sintren Art is a heritage that should be preserved by coastal population, given to the values of a strong culture in it, regardless whether the influence of magic is in it or not.

In such circumstances it becomes critical appreciation activities, one of which is to motivate and reward the artists directly, through the provision of economic aid or supports in developing its art goals, as teaching material in schools that is as the local content of the extracurricular section. From still limited researchs done it can be interpreted that still small effort in documenting sintern traditional art that slowly against loss or marginalized in reporting it. But, it can be fostered through developing the spirit of art in our future generations through by way of reviving the real environment. When you do not understand the art traditions of Indonesia, it would be nice to neither denounce nor justify the indiscrimination in improper manner.

On this occasion, Sintren traditional art that has a strong tradition and rooted in the coastal population will be reviewed. Sintren enriches the long lists of ancestor's cultural heritage of Indonesia. Starting from the beliefs of the local people towards ancestors inherited or can even be started from habitual or ordinary folk games which become a noble tradition (Yudhisthira, 2007: 125).

Basically Sintren art contains deep philosophy, as well as asset and pride of the coastal communities in the north of the border, but now its fate has turned into marginalized by a single organ performing arts, such like dangdut and pop art that are now glowing until the countryside. Meanwhile, there is a tendency of younger generation to give less care and desire to continue, develop and preserve the existence of traditional art in their environment. Despite laws protection in preserving the national culture has been strengthened by the Minister of Education and Culture Decree No. 014. Ga/U/8, dated July 13,1987 , concerning the developing and growing appreciation of traditional arts and artistic creativity with the excavation of efforts, development, dissemination, and improvement of the art quality in society.

Not to mention also the high external challenges, because of the lack understanding of the Indonesian arts and their art traditions, that can create the phenomenon of antipathy towards traditional art of any kind, including Sintren. The phenomenon that expresses antipathy towards traditional art is unhealthy and irrespectable, whereas, Islamic religion culture has taught the people to respect for in any case. People 
are finally carried away with the dialectics paraphrase and talk alot about what can and can not do, God or evil deeds or halalharam, polytheistic and heretical in arts activities. Even too easily speak law to confront against art to the statement of polytheistic of Sintren artistic traditions. As concerns, the Sintren traditional art forms being gradually marginalized by the swift currents of popular art. When you do not understand the art traditions of Indonesia, it would be nice not to indiscriminately denounce and marginalize on the pretext of the "un-Islamic". On the flip side of artistry itself, Sintren art faces changes in society and in socio-cultural envi-ronment, as a result of modernization and globalization technology progress.

Do not worry too much if the declining of sintren art in the north coast of Java border areas, has been metaphorised as the declining in the consciousness as one of phenomena in the history of the community. As of the Soedjatmoko writings (1976: 9-15; 1985:48, 1995: 358369) have reminded the importance of it as an Indonesian nation that has a sense of history. The awareness of history is defined as a continuous reflection of the complexity of the changes (continuity and discontinuity probability), caused by the dialectical interaction of people who want to break away from the grip of reality. With a sense of history, people try to appreciate the complexity of the effort at the gradual disclosure of events that surround them, and appreciate the uniqueness of each situation; even it is studied as a trend. Therefore, the awareness of history helps people alert in thinking too simple, analizing too superficial and receiving too easily patterns of law directed to the course of history or to the grip of historical determinism.
Historical awareness has also meant to avoid facing trends in the blind phenomena (Soedjatmoko, 1976: 14), or because of instant political utopianism as a result of sharp frustrations and radicalism containing fundamental issues about the nature of human nature as it is depicted in George Orwell's novel in 1984 imagining vision of "telos" or "public purpose” (Kartodirdjo, l99oK: 270). As stated by Namier (1957: 375) that historical consciousness is an intuitive understanding of how something does not happen (whereas, how something happens is a matter of a special knowledge) becomes the goal of the study of history. Given the wide range of historical consciousness has also a continuous reflection that can liberate man from the sense of self-paced credulous: rejects completely mytho-logics, and can circumvent instant utopianism and refers to a search fulfillment of the basic human needs to define and validate the identification of self in the life of society, and nation or state. Soedjatmoko called intellectual orientation as creative, introspective, and unceasing introspection. In this case, it includes businesses to the existence of life in its sociocultural configuration, giving rise to the location of awareness of the presence of life itself in its entirety. Thus the necessary of identification measures are carried out, the introspective highlight to the subjectivity itself through doing their own thinking (thinking about our thinking) and so on.

In detailed, Kartodirdjo (l990: 204) describes the self-consciousness as immanent for self-reflection that will strengthen the potential to: (l) put himself in the position of the sociocultural and temporal contexts (2) regardless of cognitive attention, place the practical life 
in the demands of theimplementation of the functions of normative concern or interest in the life-ethic history with theology, such as political-cultural orientation, (3) help to find answers to the problems such as meta-historical depiction of the future and involve predictive function of historical studies. In line with this opinion, Barzun (1974: 131) states that the history galvanize the human spirit to be strong and resilient in facing terror and chaos in our lives. Modern life demands the intellectual tools to understand the depth and meaning, so it is not tied or glued to the sheer novelty, and able to emancipate themselves from the seasonal volatility, more so than the pressure of social forces, and like what was said by Langlois and Seignobos, "history has hygienic influence on our soul because of the nature of the all- mere exempt trust “(Kartodirdjo, 1992: 21).

If people realize the possibility to contribute to shape the future through providing a space for artistic freedom, they accept that responsibility as part of the affirmation of freedom. Then, history is no longer a satisfying human curiosity, or as a source of admiration and narcism, but it is very important for meaningful participation orientation to human life. This is where the importance of the historian in Indonesia as Reinhold Niebuhr called emancipatory impulse (Niebuhr, 1949: 29). Emancipatory impulse is essentially a search of encouragement and enforcement of "freedom" of itself and the community to increase the likelihood of success in the "control" of the fate. In this case, a historian must be able to demonstrate their freedom to determine his responsibility.

\section{Identification and Problem Formulation}

Problems that arise in the analysis of Sintren traditional art, revolve around the background of the emergence of the art performance, especially for coastal communities in the border areas of West Java and Central Java. Furthermore, from the performance background of Sintren art the purposes can be traced- a traditional art performance is not only as an entertainment to fill someone's spare time, but is also as an interesting performance because it is mystical and has magical power.

While other issues that are also less important to be studied is how the stages of Sintren art performances is packed into a traditional performance art that appeals to the surrounding community. The Sintren philosophical values contribute to the History learning. For Sintren traditional art teaches identity, refinement, devotion spirit to the Almighty, as the learning of obedience to The Almighty God. But, on the other hand, Sintren art has high philosophical values therefore as national assets that is now neglected, especially by the youth and community where history awareness are still lack, in order to keep preserving and developing the arts as a premier art reflecting national identity or Local Genius and Cultural Identity that to be proud of, despite the law to preserve the cultural heritage values has already been created since the new order government era.

The formulation of the problem is derived from several following questions:

1. From which word, idea or area was the birth origin of Sintren performing arts in the north coastal areas of the border of West Java and Central Java? 
2. For what purposes are Sintren performing arts staged in the north coastal areas of the border of West Java and Central Java?

3. How stages in Sintren art are played so Sintren can be enjoyed as ordinary folk art performances?

4. What philosophical values that can be given, especially in the contribution of Sintren art to history education?

5. How efforts are done to increase the awareness of local history, especially in preserving and developing the increasingly marginalized Sintren arts?

Based on the formulation of the problem that has been stated above, the purposes of the implementation of the study are:

1. to analytically describe the origins of the Sintren performing art at border area of West Java and Central Java which was unique and magical, but now it has been drastically marginalized by the arts of global popular culture.

2. to explain the objectives of the Sintren performing arts since it was staged in the past but the dynamics are still on at present.

3. to analyse the stage performances of Sintren performing arts from beginning to end, as well as its dynamics especially when it is compared to Sintren performing arts in the past and at present.

4. to analyse the philosophical values that can be drawn from the Sintren performing arts for HISTORY learning in formal schooling.

5. to explain the concrete efforts that have been done by both the actors of the Sintren performing arts and the local governments, in maintaining and developing the Sintren performing arts so that it is still exist in this global era.

\section{The Urgency of Research}

1. Historical-ethnographic studies that analyze in depth the Sintren performing arts in coastal areas in the north of the border of West Java and Central Java, as arts and valuable cultural assets in the development of the nation's character are felt still limited;

2. The importance of the study of social values and thriving culture of Sintren performing arts at the border of the north coast of West Java and Central Java that can be transmitted, revitalized and transformed to young people and to the community, becomes apparent attempt to bolster the nation's cultural resistance that is now felt crises of identity in the art and culture of the nation.

3. Strengthening and preserving the local culture by cultivating and developing the basic values of "national identity" (local genius), is a manifestation of the development of history consciousness as to be creative, introspective, and have intellectual orientation and unceasing introspection. In this case includes the businesses of putting themselves in the existence of life including its sociocultural configuration, and rising the awareness of the presence of life itself in its entirety.

\section{Research Methods}

This study uses a combination of historical ethnography methods. In Indonesian Encyclopedia, ethno-graphy is a branch of anthropology, is a portrayal and analysis of the 
culture of a community or tribe. Ethnography usually consists of a detailed description of the aspects of how to behave and ways of thinking that have been codified in the people being studied, such as text, photos, images or movies containing the report or description. Studied by ethnographers are cultural elements of a societysuchas, language, livelihood, technology systems, social organization, art, knowledge systems, and religion.

Ethnography is one of the qualitative research approaches. It is used to study human behaviors associated with the development of a specific culture. Ethnography is an early version of community cultural elements such as language, livelihood, technology systems, social organization, art, knowledge systems, and religion (Spradley, 1997: 4). New ethnographic analysis in this study is not based solely on the interpretation of the researcher. While modern ethnography is a major concern to the researchers, especially regarding the present life, which is about the way of life of society (Spradley, 1997:5). Ethnography usually contains / tells a tribe or society and their cultures. As an ethnographer typically examines the holistic approach and describes it in depth for gaining native's point of view. Data collection techniques used were in-depth interviews and observasion participation in which the method of data collection is in accordance with the initial descriptive depth goal. While the documentary studies are used to reveal the Sintren classic or traditional songs and its dynamics when it is staged (Cresswell, 1994: 8-9).

Reason of choosing the Ethnographic methods to be used as a reference of this study is because they have some advantages. This method reveals ethnographic journey from the early to the new form of ethnography. As well as providing practical steps to conduct ethnographic research, in Cresswell's term as new ethnography, which is then used to intreprete the world, and develop strategies for behavior in facing it. Meanwhile, the lackness of this ethnographic methods lies in the view that this method only observes traditional or isolated communities so the researcher uses this ethnography as a fundamental tool only.

While for the historical aspect of this research the historical method was used (Sjamsuddin, 1996: 63). It is a method of research that reveals how to know the history of something. The reason why the researcher uses the historical method, because the issues raised are Sintren history issues that happened in the past that became Sintren origins and its dynamics and up to present.

Furthermore Sjamsuddin (1996: 69) reveals several steps that must be performed by a researcher in the history of doing historical research, namely:

1. Choosing an appropriate title or topic.

2. Investigating all evidences relevant to the topic.

3. Making a note of what are found during the study.

4. Knowing all the physical evidences that have been collected (source criticism).

5. Compiling the results of research into a proper or systematic pattern specified.

6. Presenting and communicating to the reader in a way that can attract attention, so it is understandable (Sjamsuddin, 1996: 65).

From those sixth steps, the first stage of choosing a topic, by determining the " Sintren Performing Arts " then we select the topic, the background and the various reasons that the researcher asks. While 
in compiling all evidences related to art Sintren, the researcher attempts to collect historical sources about Sintren art, whether in the form of object, as well as oral or written documents. Furthermore, researchers are making important records following the heuristical step; while in evaluating all the evidences, historical criticism stage to Sintren art sources was applied. While the last, compiling all the results of the research, and presenting it in a research report and article that becomes a stage of historiography.

The research conducted from June until October 2012, with locations were in the north coast of Java, the border between West Java and Central Java, especially in Indramayu, Cirebon, Brebes. The subjects of this study used Sintren actors (The Sintren itself, handler, gamelan, and connoisseurs of Sintren) who were located in four districts.

Some of the Sintren art groups used as subjects or resource informants of this study were: First, Sintren group from Indramayu district, Dandan Ayu Putri Jaya, with its Manager: Mr. Tarwadi (45 Years), handler: Tarmudi ( 54 years), Sintren Dancer: Inka (14 years). Second, Sintren group from Cirebon district, Sinar Harapan Cirebon, with its Manager: Ms. Juju (46 years), handler: Mbah Riwig (70 years); Sintren Dancer: Naripah (15 years). While the third, Sintren group from Brebes district, Nada Ocean, with its Manager: $\mathrm{Mr}$ Miris (47 years), Sintren Dancer: Ani (13 Years), handler: Ibu Dasuki (64 years old).

For the connoisseurs of Sintren art subject/resource persons used in this study are: 1. Head of Youth, Sports, Culture \& Tourism (Kadisporbudpar) of Cirebon City: Dr.H. Wahyo, M.Pd. 2. Head of Youth, Sports, Culture \& Tourism
(Kadisporbudpar) Cirebon District: Drs. Aslich Abidin, M.Pd. 3. Headmaster of Lelea Elementary School I, Indramayu district: Sugiarto, S.Pd. and 4. A humanist fom Brebes District of Central Java: Arthur S. Nalan.

Data collection techniques used in this study were observation, interviews, and documentation. All of these techniques are hopefully complementing and supporting among another in obtaining the necessary data. Thus, this study will include data such as quotations, whether from literature studies, interviews, fieldnotes, photograph, video-tape records, personal documents, notes/memos, official documents and others.

Observation notes done by researchers were date of observation and recording, the observation/ recording (to the situation in the community), the original recording or not, and observation/recording. While the notes were made related to the informant and included name, age, gender, occupation, education, ethnicity, position in society, active or no in watching Sintren art performances. As for its documentary, the researcher gathered information from Sintren documents, such as its equipment or gamelan (pitcher gembyung, bamboo fans, tube lodong, drums, xylophone saron and bonang, gong, organ, guitar, etc.). As well as sets of equipment such as Sintren and Bodor clothings, flowers incense and perfumes, incense, incense burning places, and cosmetics. To complete the study, the researcher also observed song documentary through listening Sintren art songs lists sung from the beginning to the end of the show.

Data reduction is defined as the process of selecting, focusing on simplification and abstracts and rough transformation 
that comes from written records in the field. Then proceed with the presentation of the data (data display) in the form of descriptions based on the aspects are researched and continuously compiled in analysing Sintren art. The conclusion or verification, in this case, the conclusion was done in gradual stages, first in the form of tentative conclusions, but by gradually increasing the data, it is necessary to verify the existing data that require to be reexamined (reduced or presented). It was also done through asking the consideration from those parties related to this research (Miles and Huberman, 1992: 17): the perpetrator or Sintren, handler, and gamelan musicians, singer/including its backing vocals, as well as Sintren connoisseurs.

As mentioned in the previous chapter, the northern coast regions, PanturaPantai Utara, the border of West Java and Central Java that include in the study are Indramayu district, Cirebon regency, Cirebon city and Brebes. For the samples in Indramayu district, Losarang District with its Sintren Group Ayu Putri Jaya Dandan, with its Manager: Tarwadi (43 years), handler: Turmudi (43 (years old), and Sintren: Inka (Junior High School Students Class VII). From Brebes- the Sintren Manager: Miris (54 years), Sintren Dancer: Ani (primary school graduate or 13 years) and the handler Punduh: Ibu Dasuki (61 years). While Sintren art from Cirebon regency led by Ms. Juju (54 years old) with the name of the Group: Sintren Sinar Harapan, Manager: and handler: Mbah Riwig (62 years).

\section{Research Results and Discussions}

In this research, steps began with making a simple research tool, interview that includes: (1) The origin of the birth of the Sintren performing arts in the coastal border of West Java and Central Java, (2) The objectives of the Sintren performing arts staged in the coastal border of West Java and Central Java?, (3) stages were played in Sintren art that can be enjoyed as ordinary folk art performance, (4) philosophical values of Sintren arts that can contribute to history education, (5) efforts to increase awareness of local history in preserving and developing the Sintren arts that are increasingly marginalized. In addition, to complete this interview, observation and documentation are also applied. The results of this study as a whole are as follows:

First, the origin of Sintren art was located in the border coast of West Java and Central Java, its certain location no one of the respondents knew, because of its very long backround of journey. Most just assumed that Sintren art began since the 1940's (during Japan Era) since its birth, Sintren art could not be separated from the struggle against the invaders. A slightly different opinion, argued that the existence of Sintren has existed since the Dutch era in the 1930s. "This argument is also reinforced by the humanists, because the term "Sintren" itself comes from "sinyo" which in Dutch means "youth" and "trennene" or "exercise. Although there is also the opinion of the word "Sintren" comes from the word "sesantrian" means "students play lais mimic, whistle, or Ubrug rudat and using magic".

Meanwhile, according to a humanist from Cirebon, Nurdin M. Noor, who suspectsed that Sintren was another name for the God Indra Jaya, known in the puppet world. But Noor admitted his uncertainty because it was only based on 
the virtue of the strains that accompanied the song lyric of Sintren art performance, that are poetic described as follow:

Turun turune sintren, Sintrene widadari, Nemu kembang yun ayunan,

Kembange Ki Jaya Indra, Widadari temurunan

\{Come Down sintren) dancer, the angel dancer, let's find a swinging flower, the flower of Ki Jaya Indra, the the descendant of angel

Furthermore, from the strains of the poem he suspected that Sintren was the embodiment of a God or Lord Indra Jaya who was entering the body of a Sintren dancer that should be a virgin girl. Thus, the exact time of the emergence of Sintren art is not certain. Then, he continued to argue that most of the people thought that the birth of Sintren was during the Dutch era, because the existence of the Sultanate of Cirebon in West Java was at the same time as the Dutch colonization.

This was consistent with the story of the son of Ki Baurekso, Raden Sulandono, from his marriage with Goddess Rantamsari. Raden Sulandono were falling in love with a young woman from Kalisalak village, Sulasih, but their romance was not accepted by Ki Baurekso, eventually R. Sulandono went meditate and Sulasih chose to be a dancer. Despite, meetings between the two were still going on through the supernatural ways. The meetings were arranged through entering the angel spirit to the Sulasih's body, at that time, R. Sulandono who was also being in imprisoned spirits, summoned by his mother to meet Sulasih and there was a meeting between Sulasih and R. Sulandono. Since then, since every performance held, the dancer must be entered by the handler angel spirits, with a note that it only could be done when the dancer is still in a holy state (virgin).

Furthermore, regarding to the origin of the Sintren art stage has been especially discussed by the respondents as well as cultural performers from Indramayu, Cirebon and Brebes who have stated that based on the story of heredity, Sintren actual game birth origin was to eliminate boredom and pass the time. The game was created out of the habit of mothers and their children who are waiting for their husbands/fathers came home from fishing in the sea.

Rather than sleeping in the afternoon, while waiting for her husband or his father came then Sintren game created. But who created the first time, there is no source mentioned. Since during the ancient times there has been no authority, so togetherness became priority, including on this case of course. Because it was often played almost every afternoon, then, eventually Sintren becomes an integral part of the lives of the coast community. During its development, Sintren had been a full mystique game. In further developments, Sintren was played by fishermen walking around the village for the purpose of making money taken from the saweran, as their income and as objects to make a living.

Turun turune sintren, Sintrene widadari, Nemu kembang yun ayunan,

Kembange Ki Jaya Indra, Widadari temurunan

\{come down (Sintren) dancer, the angel dancer, let's find a swinging flower, the flower of Ki Jaya Indra, the descendant of angel\}

The melancholy shrill singing voice from the mouths of theinterpreter or kawih, 
heard repeatedly in the cool but dry air night on the northern coast, accompanied the dancer who put in a chicken cage, ornated by dominant tassel fabric in white color. Scented incense smoked mystically like grinning in front of the chicken cage, inviting the invisible presence creatures to actively participate in the people's party.

But mythologically, the Sintren art was born from the pretty much adopted story told in some areas, that was the true love story between Sulasih and Sulandono, whose their romance were disagreed by Sulandono's father. Through the blessing of Sulandono supernatural power, even though the couple was not able to meet physically, but through the magic of nature, with the media of the dancers, they could meet. This evident was wrapped in a Sintren song lyric as:

Si Sulasih Sulandana; Menyan pangundang Dewa, Allah Dewa saking sukma; Widadari Temurunan; Ngaranjing ke awak Sira.

\{The Sulasih Sulandana, The God Caller Incense, The God of The Soul; The descendants of angel; penetrated into your body\}

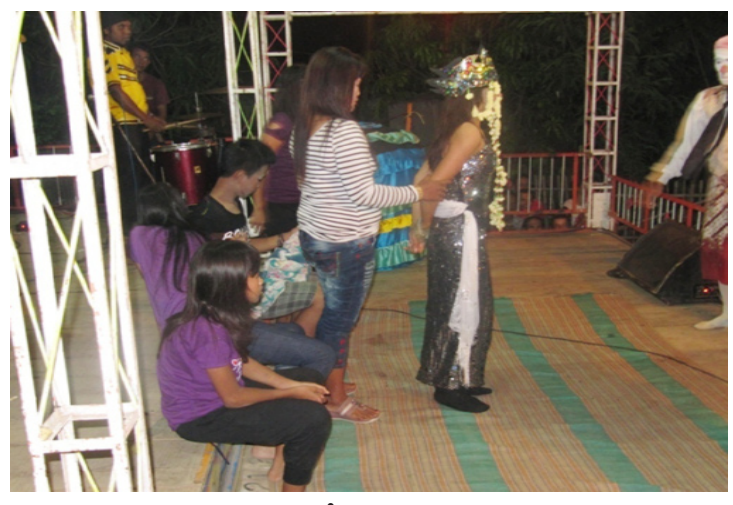

Pictures 1.1:

The first song of Si Sulasih Sulandana sung during the "Puteri Ayu Dandan Jaya" Sintren Group from Indramayu (Inka's Sintren) Performance. (Source: Research Primary Data)
The next question arised from the research was whether it was a habit since the first existence that Sintren dancer should be a holy and pure girl? To the question, almost all respondents, from the Sintren group manager, handler, until Sintren cultural coast observer agreed that "chastity" or "purity" of a Sintren dancer should be completely assured. If it was traced from the roots of its history that told the tragedy associated with the legend of the Kasepuhan palace which splitted into two parts in 1697, right after the death of Sultan Sepuh I, due to Dutch conspiracy that had permeated the lives of the royal palace to the inner circle center. Each occupied by Dipati Anom and Aria Cirebon Princes. The grim political situation had made an aristocrat such Raden Sintren preferred to live as an ascetic.

From the silence spiritual contemplation, then he met a girl from the peasant saint, Sintren or Lais. She was a virgin who had experienced a spiritual awakening as it had undergone psychotherapy practice with a high level of discipline. Raden was fascinated by the Sintren light tinged of Lais soul. Unfortunately, the love story of two derived from very different social classes then could never run smooth.

To ruin this love story, Mbah Wirogandul ordered by Raden Ayu Rara Rainara was asked to perform rituals to test the Laish' virginity, hoping it would provide results that could hinder his romance with the poor girl. On the night of the full moon, the rattan long rope was tied up around the naked body of Laish or Sintren, with her eyes were covered by a cloth. The seven-flower Water was poured over the shrine girl head that had been put in a chicken cage, accompanied by the 
ancient mantras from the mouth of Mbah Wirogandul. The group of musicians or nayaga started playing gamelan pounding with monotonous heave gripping poem:

"turun turun sintren/sintrene
widadari..., nemu kembang yun-
ayunan....."

\{come down (Sintren) dancer..., let's find a swinging flower ...\}

While sitting cross-legged and meditating whispered spells, Mbah Wirogandul hand gestured to stop the mystical choir. He explained in brief that if the chicken cage open, a figure emerging in a nymph wedding dress, the woman was still virgin. But otherwise, if the Lais had already been touched, the woman would appear in a bound rattan, stinking, and surrounded by thousands of caterpillars. What happened next was a wonder. From the chicken confinement, a figure, widadari Lais/Sintren was in a graceful bridal gown glowing and dancing without stopping. Raden Sintren was bowled over and tried to touch her. But unfortunately, every time he touched her, suddenly the Laish fainted, and the happening was always repeating. The Lais/Sintren now could be unattainable by any mortal, even in the name of love. Her spirit had now become a moksha and belongs to the universe.

Second, the objectives of the staged Sintren art performance. Several respondents who were either performers or cultural and art connoisseur, said that in the beginning, this staged art came from the habit of mothers and their children waiting for their husbands/fathers came home from fishing in the sea. Instead of sleeping in the afternoon, the fishermen who did not go fishing, created a better game. Whereas other's opinion argued that in Brebes, this performance was previously the art of asking for the rain, and was particularly performed during dry season. Certainly not a few who think that Sintren performance goals are to maintain and develop the awareness to the traditional art that is almost extinct, as well as for commercial purposes, or for a living in this life that is full of hardships, through waiting for the saweran money, or an invitation from people to perform their sintren art.

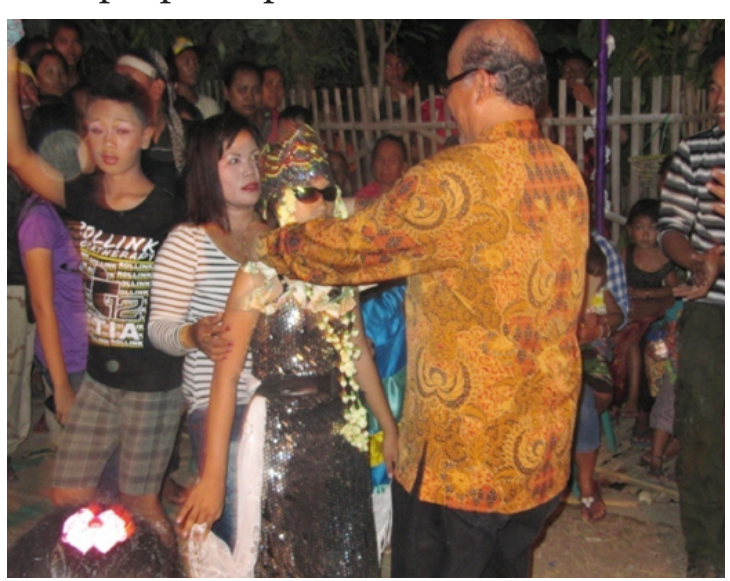

Pictures 1.2:

The audience was giving the saweran money to the Sintren (Inka), from the "Puteri Ayu Dandanjaya" Sintren Group, in Indramayu District. (Source: Research Primary Data).

It can be concluded that, formerly, Sintren art performance was staged as a suburban folk art, and held constantly in certain villages almost every afternoon, and became an integral part of their lives; then over the time, Sintren turned into a sacred game to waiting for the fishermen home. Until now Sintren becomes a noble cultural heritage that needs to be preserved. In further development, the Sintren arts played by fishermen around the village for a gig anywhere, and apparently from the circumference of the money for living, they are also getting a pretty good saweran. From 
the beginning, Sintren became a way to earn and have extra income for their living needs.

It can be simply reconcluded that according to the instigators of the Sintren art, there are two sintrenan styles based on the time of performance. First, Sintren is deliberately held freely, without being limited by wayah (time), the time here is usually associated with the season, this Sintren type performance is often held in various celebration events: weddings circumcision orjust welcoming government guests. Sintren staged in the first type is more familiar to the community with the commercialization of entertainment. Second, the Sintren performance held within certain times is typically held during the drought time, but it is usually held for 35 to 40 days. This type of Sintren is believed as a ritual or as rain caller. The later type of Sintren is more widely performed in the remote villages that still has not been touched by the progress of science and technology, in a simple community when Sintren art has not been commercialized yet.

Third, the stages of Sintren art performances are as follows: (1) the preparation phase involves: (a) equipment or Gamelan (if it previously included gembyung, tube or bumbung, and used bottles, but it now includes drums, guitar, flute, organ, and speakers or a sound system, (b) Clothing (includes the Sintren complete outfit, the comedian or Lawak/ Bodor clothing, the singer or sinden/ kawih clothing, (c) the furnished or prepared chicken cage, (d) the incenses, which are always burned during the whole performance takes place, (e) the dancer/Sintren, a very young female girl; (f) Comedian Lawak/Bodor, virgin male Sintren whose age may slightly older that the female; (g) Punduh or Sintren handler; (h) spokesmen kawih/singers about six people; (i) Sintren songs shows from the beginning to the end. (2) the performance stages. In this case, the Sintren girl dancer candidate, wearing previously Cirebonan casual dress, with no make-up, and was tightly roped from her neck to toe, with her consciousness guided by the handler went into the cage, in which a package of costumes and cosmetic tools were provided. Before the Sintren dances, the interpreter kawih started singing the songs that were meant to invites the audience in a poetic way:

Tambak tambak pawon; Isine dandang kukusan; Ari kebul-kebul wong nontone pada kumpul

$\{$ kitchen wall, kitchen wall; Its content is a steaming pot; and it fumes when people are watching the gathering\}

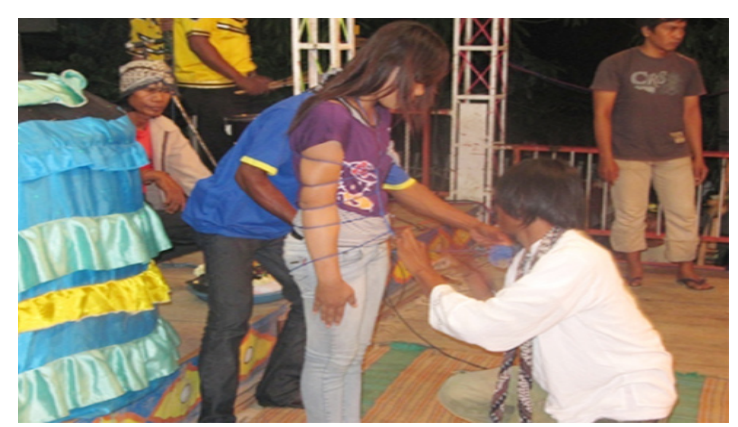

Pictures 1.3:

The Performance of Sintren dancer (Inka) from "Puteri Ayu Dandanjaya" Sintren Group, Indramayu in an acrobatic performance through self tied from shoulder to toe by a handler named Tarmudi (Source: Primary Research Data).

Or it could be in some coastal areas of West Java particularly in Indramayu, initial or opening song was "Turun Sintren", which its verses were as follows:

Turun-turun Sintren; Sintrenne Widadari; Nemu kembang yun-ayunan 2X; Kembange Si Idra Jaya; Widadari temurunan 
\{come down (Sintren) dancer, the angel dancer, let's find a swinging flower, let's find a swinging flower, the flower of Ki Jaya Indra, the descendant of angel\}

The song was repeatedly sung until the crowd really gathered to watch the Sintren show. By the time the audiences gathered, the Sinden began reciting the next song. Before the Sintren dancing, the interpreter or kawih/Sinden started singing the songs that were meant to invite the audience. Its verse was like this:

Tambak tambak pawon; Isie dandang kukusan; Ari kebul-kebul wong nontone pada kumpul

\{kitchen wall, kitchen wall; Its content is a steaming pot; and it fumes when people are watching the gathering\};

After that followed the song of Kembang Tarate, with its verses like this:

Kembang trate; Dituku disebrang kana; Kartini dirante; Kang rante aran mang rana.

\{Lotus flower; purchased from the other side of the street; Kartini was chained by an uncle named Rana\}.

In the middle of kawih above, the Sintren who was still very young came. Later, the chicken cage was opened and she had just changed her costume, with thick make-up and black glasses, and dressed in a sleeveless liked puppet costumes, wore $3 / 4$ black pants, with a belt width of cloth wrapped around the waist supporting a sampur (a traditional weapon), adorned with jasmine strands on either side of the crown, and a black-white stockings, but still sat tied to a rope. The cage was closed again, with the strains of an increasingly wrenching night Sintren song. Once the chicken cage was shaking, swaying, and the handler lifted it, and she was no longer bound. She immediately got up and danced as the beat of gamelan, with a choreography that looks more like a mix between dance and ondel-ondel \{Batavian Traditional Gigantic Puppet\} and Kungfu drunk masters; instead of the traditional dance with the grip motion diverse aesthetically. She was possessed by an invisible creature, an angel or widadari, which since the beginning of the show has got an invitation through the incenses. Motion was consistent with the inconsistencies dance style. Sunglasses that actually functions to shut eyes closed when the dancer becomes possessed by one of the appeal.

According to the respondents, it was said that a Sintren should be a virgin girl, if Sintren was played by a married woman, then the show was considered unsuitable, in this case. Although there was no clear reason to explain further about what was suitable. "It should be deliberately a virgin," they said. Then Sintren tied with rope from neck to toe, so that it is impossible to release the Sintren bond in such a quick time. Then Sintren entered into a cage which was covered with a cloth, that also previously completed by the given supplies of clothing replacement. Gamelan kept echoing, two people described as unrelenting handler read the prayer, with incense smoke billowed. The interpreter or kawih kept repeatedly singing the songs:

Gulung gulung kasa; Ana sintren masih turu; Wong nontone buru-buru; na sintren masih baru

$\{$ Roll, roll a mat; the Sintren is still sleeping; people are hastily watching, because the Sintren are still new grace brand?.

Which described the captivity conditions of Sintren and she was still in a state of sleep.When the cage was 
opened, the Sintren had been replaced with an all-round nice clothes like clothes that were commonly used for mask dance, and wore sunglasses. Sintren then danced monotonously, the jostling crowd began throwing the coin to the Sintren, and those coins were shot on her body, then the Sintren fainted. Sintren regained her awareness and then danced after the spell was given by the handler. The Sintren monotonically kept dancing and the audience was trying to throw a coin in the hope the Sintren would faint again. Here is one of the core of the Sintren arts "I do not know, every time the money touched the Sintren dancer body, she then always fainted, it is the scene requirement" said a handler, Mamang Rana, to the researcher.

When it was asked to the Sintren dancer, Kartini (Ani), right after the show, she admitted unconscious of what she did on stage, although occasionally she felt the small objects throwing directed to her. This is still mystery whether the Sintren dancer is really conscious or just to optimize this rare performance. A former Sintren dancer (Pak Miris' daughter) who felt reluctant if her name was to be mentioned, said that she really knew what she was doing on stage, but because of the demands of the show then she should do a scene as if she was fainted.

Sintren performance was rather similar to a magic show, which was originally a female dancer who wore daily cloth after she put into a solitary chicken confinement and then put on solitary dance cloth, then in a few moments the dancer cloth had changed into special clothing for the dance. When the process of changing clothes, the incense continued rising as a sign of the encouragement of magical show.
The duration was not less than 3 hours, the staging of Sintren in Puteri Ayu Jaya Dandan Group from Losarang Indramayu was a great success. The audience barely budged from their seat until the end of the show. Then, the next Sintren art songs were mentioned to them: Ayo Ngewer-Ngewer Putren, Simba Melati, Rujak Cengkir, Bapak Tani, Kembang Oyong, Bajigur Aren hingga Pitik Walik \{Let's bring the Putren (The Young Pure Girl), Jasmine pragrance, and "Cengkir" fruit salad, peasant people, squash flowers, "Bajigur" palm sugar drink, and walik chicken (chicken with inverted head)\}, and so on. (3) The closing stages. Usually after giving the sawer money, and all the seats were deserted, the Sintren girl crouched and it was closed by Orok-orok songs, which the verse was like this: Orok-orok; Banyu bangrimapar tembok; Wong nonton pada udodhok; Sintren metu salin erok B Baby baby; water splashing against the wall; those who watch are still sitting; waiting for the dancer replace her skirt\}. When the cage was opened, Sintren dancer appeared dressing in a previous plain dress before she entered the cage, in dark glasses, and her hands were tied, she was unconscious. The handler read the rhyme until she woke up. The show was ended by Ulungulung tune-eminent: Ulung-ulung Simbar Wulung; Sing Wulungpatine laying; Ala gandrung eling-eling; Ayo si... (calling the Sintren dancer)... pada balik.... \{Master, Master The Eminent One, flashing the Wulung Juice; with conscious devotion, Let ... (calling the Sintren dancer)... go home\}. At the end of the song the Sintren dancer began conscious again, and usually she blushed and she ran away from the audience 
Fourth, the philosophical values that can be contributed to the history education. The answer is the first to firm the genius local identity of that area. Then Sintren itself is the meaning of human life that is bound by norms and rules. Confinement is a symbol of the world and norms. Basically the man is locked up in the world. He must try to free himself from the captivity as did in Sintren. When the world and norms confine, people have the strategy to challenge this confinement. We have the sense to free ourselves from the shackles of life. Then why Sintren art is staged with orchestra and simple equipment? To this question there is an answer: "There are three main important things in the Sintren performing arts: First, the sinden, who rhythmically monotonous steady spells, that becomes a leader for the whole show. The overall sound of the music, essentially was merely accompaniment of the rhythm of mantras recited monotonously to facilitate the formation of the trance of the Sintren dancers. Second, the mastermind, who is behind all the performances, whose function himselfas a director, healer, as well as handler. Third, the subject and object at the same time of all the performing arts is a Sintren dancer herself. Reciting the mantra - the spell of a puppeteer, blown on the dancer during the show. Songs sung and spelled by singers can move the subject, the dancer. From the sky, the eternal virgin angel, comes down to earth with a borrowed body of the dancer as an object. That is why Sintren dancers should be a virgin. On the full moon night the fairies come to the earth, the souls of pure women. That is why the Sintren ancestry requires a dancer who is virgin even has not got her first period. The Sintren dancer is subject and objects of the show".

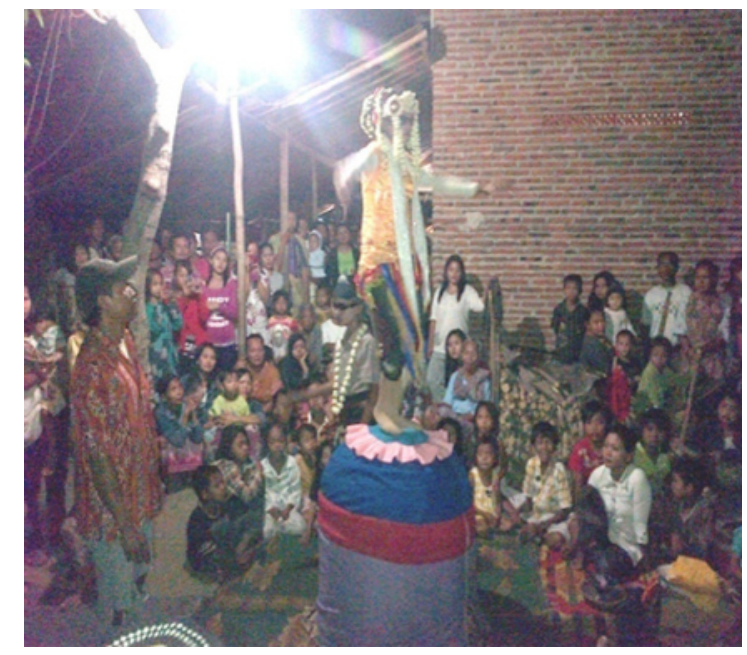

Pictures 1.4:

The display Sintren performing arts (Ani) from"Nada Samudera" Group, Brebes:, an acrobatic show with dancing on the top of a cage. (Source: Research Primary Data).

The role of subject and object of this performance was increasingly felt, when we tried to enjoy the lyrics of the song as well as a mantra, sung by the singer in circles around the chicken cage, where in it, a fairy attached dancer body lied. They, the singers, while circling the incenses, were chanting the lyrics of the following mantra:

Turun-turun sintrén, sintréné widadari, Nemu kembang yun ayunan, nemu kembang yun ayunan, Kembangé ki Jaya Indra, widadari temurunan

\{come down (Sintren) dancer, the angel dancer, let's find a swinging flower, the flower of Ki Jaya Indra, the descendant of angel\}

The lyrics of the song was repeatedly but monotonically sung, with too monotonous musical accompaniment, that have made it easier for the dancer to go into a trance. It is mandatory in the sintren show incantation. And behold, if an angel had descended into the body, the miracle happened to a sintren 
dancer. Before being put into a cage, he just dressed frumpy without makeup. While the whole body was in a state of perfect bound, locked in a bond with a padlock, but after one looked at the mantra songs sung, and the inviter angel came, then the cage was opened, the singer dancer had changed her clothes with charming make up, although she still remained in a state of perfect bound as before. While tattered cloth was folded neatly in her lap and replaced the now wearing new clothes.

Or look at the wonders that could be witnessed next. After the confinement returned to be used and opened, the dancer had now released all the chain straps. Dancing and jumping fit to the lyrics charms. We could see there would be a miracle sintren dancer jumped onto the fragile chicken cages, and even also on a roof tile of a house. It is a miracle that can not be haphazardly done by handler or pawang. So well as in general, when the dancer hit by the saweran from the audience, she immediately knocked unconscious. But it was very easy solution. Pawang in order to keep Sintren conscious, he would immediately hugged her, and asked the singer sang the lyrics of the following mantra:

Kembang ki laras, beras abang putih kuning (2x); Wong nontone aja maras, dalang sintren joged maning;

$\{$ Ki Laras flowers, red white and yellow rice (2x), All people who watch do not feel worried, cause the mastermind will dance and dance again\};

All the audience did not need to worry, because the sintren dancer would dance again. Thrown money saweran symbolizes that man fell because the property, if he has a lot of treasures that he could fall unwittingly into pride and arrogance that he became the most powerful man. Sintren dancer usually wears sunglasses to cover the position of the eye during trance.

Some meanings behind sintren contain, among other things: the First, mythic meanings that have relationships with the acquisition of magical. This is reflected through the songs sung by the simple and monotonous but able to give specific power, so sintren players eventhough in the conditions of strongly tied off she dress in seconds; the second, thetheatricalmeaning. Theatrical meaning is illustrated by the appearance of the handler with sintren players and confinement simultaneously. Then, the sintren dancer changes her appearance since she is tied up and put in a cage and comes out again and go back in the cage.

The philosophy in human life explains that when a man is at birth, he is pure and clean, but without any clothes on. Confinement symbolizes the world. Rope is considered as a bond between man and Allah SWT. Frankincense symbolizes a sense because humans have a taste, creativity and initiative that makes people become perfect beings. Thus the classical arts, Sintren existence can not be separated from the cultural values that contain moral messages, and it is not just art for the entertainment, but there are certain messages behind the play. However, the messages in the staging of Sintren are abstract and not everyone is able to catch it.

Turning on the Sintren art is nothing more than a devotion to preserve cultural heritage, or to maintain the values of wisdom reflected in it. Maintaining the artistic values are presumably also taken into consideration. Decision to become a 
Sintren dancer perhaps requires a moral courage and sincerity that should be appreciated as a form of keeping the values of chastity.

In the procession of Sintren staging, there is a strict prerequisite that the dancers should be a virgin (pure) physically and spiritually, and must remain chaste (not to be touched by men) is a big challenge in the modern world system that is full of morale decadence due to the increasingly negligence to the values of life. A girl's chastity is the line of morality, which can only be maintained with caution. Talk about a girl's chastity that might be considered absurd in the life of young children today.

Then what about the polytheist traits exhibited in Sintren art? That question also can indirectly lead public opinion to judge and unilaterally define that Sintren is worship arts activities and misdirection, it is as if compulsory eliminated. And slowly, our assumptions against all forms of traditional Indonesian art turned to Islamic and nonIslamic art.

Looking at the tendency of some groups who indiscriminately classify traditional arts, we can sort out clearly; whether the art derived from Arabic Jazirah (read: the Middle East) is called Islamic art and the art which does not come from the Arabian Peninsula was not included as Islamic art? So, what's the difference of Belly Dance (belly dance which is by origin from the Middle East ) with its rocking (drilling) style resembled Inul Daratista style (Dangdut Singer) from Indonesia? People are finally carried away with dialectics paraphrase between halalharam that have been spoken out under the authority of religious figures, and considered polytheistic and heretical arts events; even abide this falseness with strict law.
Our traditional arts can not be separated from our social and religious life, such as Jaipong and Sintren that have been prioritizing togetherness and guidance. The religion of Islam recommends that every human being should be kind to another and stay in touch with the God. Friendship can be done in various ways including through the arts. Sintren philosophy if we examine closer can be considered as propaganda for a man who lose his faith to return to his previous condition, becoming pious again. The real treasure given by the Almighty God is entrusted to us; as His Creatures, we only have the autonomy to use wisely all the properties. So obviously both Jaipong and Sintren Arts do the polytheists practices. Both arts are beautiful if we interpret in the positive way, but they will be worst if we interpret in negative way.

As Muslims in particular, tolerance to the traditional art was once told by Rasulullah Peace Be Upon Him. Such as when the Prophet respect a people who did artistic expression, one of them, is narrated by Aisha: "That when the Messenger of Allah came into my house, there were two girls by my side playing tambourine while singing, which was later reprimanded by Abu Bakr, but the Messenger of Allah stated: Just go on, because every people has his happy days "(Narrated by al-Bukhaari, al-Jum'ah 897).

Or, when "Abu Bakr asked permission to enter the house of Muhammad PBUH, while at his home, there was a woman who was singing while playing a tambourine, then came Umar (the woman was still singing), then Uthman came, the girl stopped singing. Muhammad PBUH said (commented): Uthman was a shy person “. (Narrated by Ahmad, al-Musnad Kufiyin 18325). 
Regardless to the tendency for the legitimacy of defense against the wealth of traditional arts and culture of Indonesia, the two hadith above have explained about the culture, at least we can learn a lot of things: how the Messenger of Allah respects the tradition and all forms of Tahniah art existing at that time. In other words, the attitude of the Messenger of Allah is persuasive attitude reflected as a rational and civilized moslem, in order to introduce the essence of the Islamic teachings in a gentle mannered and full of love.

Of course, there were many prophet attitudes that explain how to live with tolerance and respect and deal with the activities, rituals and performances which were shown in a nation at that time. Certainly, the Prophets always expressed all the behaviors in ways that did not hurt or even use harsh languages that would kill the creativity and potential of each human being, even though, in certain case, the Prophets explicitely prohibited even forbode such behaviors.

As it had been done by Sunan Kalidjaga one of the Nine Guardian or Wali Songo, in spreading Islam in Java when the Sunan used puppet or Wayang as his media to infiltrate Islamic teachings in Java. Wayang was art devices that were first born before Islam came into Indonesia that is during Hindu era and also used for Hindu teachings and messages passing. Thanks to the Sunan anyway, because at the end, the Javanese-Hindu voluntarily embraced Islam and has now spread throughout the archipelago.

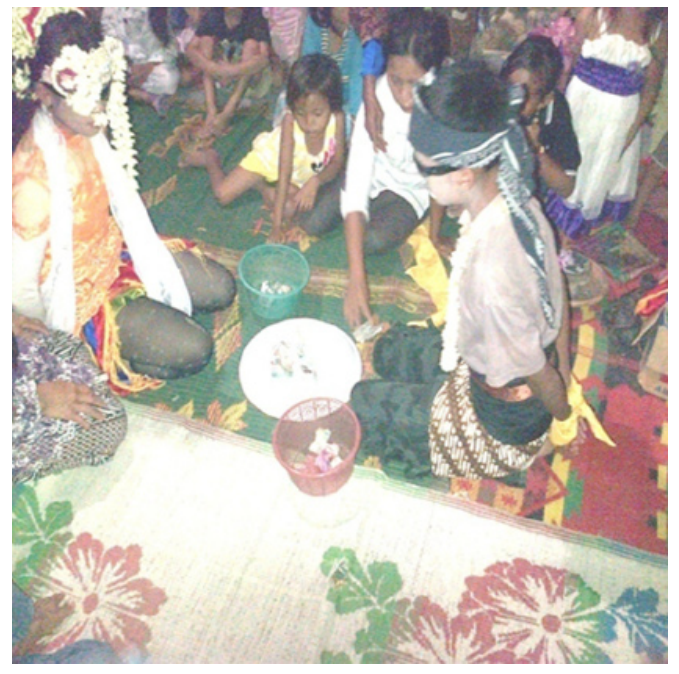

Pictures 1.5:

Sintren (Ani) from "Nada Samudera" Group, Brebes: counting saweran money using the mouth when singing Uwa-uwa Bango Song. (Source: Research Primary Data)

Fifth, efforts to increase public awareness of the history of the north coast in maintaining and developing the art Sintren. Especially in Indra mayu in preserving and developing the art of exposure Globalization Sintren turns on SDN LeleaI-Indramayu: "Sintren art in elementary school become an annual event staged in order to preserve the art and culture of the area to remain awake and not disappear into a globalization that often infiltrated by foreign cultures ". In addition, the students are also some of them able to sing Sintren songs, because they also continue to learn so that they can sing. They believe that the local culture should always be maintained and preserved in order not to be extinct, and have a shared responsibility to keep watching the actual existence of local culture that has incredible potential. 
Sintren must also be grown as the concern of the community to the deterioration of their local art and culture that should actually be improved to be used as local commodities or assets. To preserve this culture, guidance is required by the students in order to comprehend and be able to perform the sintren art.

The art and culture that have been fading away because of the advancement of the globalization era reflected in the inclusion of negative culture from the outside is expected to be explored by the potential students in order to be maintained and preserved. It is said that the application pattern of sintren art in school has become initial efforts that is implemented through students' instillation to the values of loving their own art and culture and also through digging the talent and potential of students, to show to the community that the local arts and culture heritage is still available to be performed and sung well by the students.

Unfortunately, the government and schools still give little concern to the incorporation of Sintres art to be developed and integrated in school curriculum and have been given total supports from and it is also fully sponsored by the local government. Just as comparison, the conservation and development of the Sintren art has ironically less developed in this area of the sintren birth origin if we compare to the sintren development in Kuningan regency which is actually not the origin area of the Sintren art, as seen in the picture below:

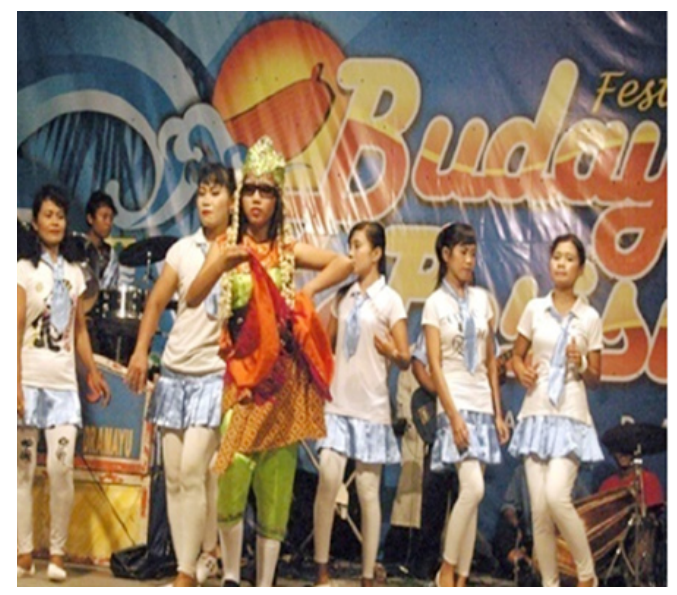

Pictures 1.6:

Ciayumajakuning's Sintren art performances (Cirebon-Indramayu-Majalengka-Kuningan) at Kasepuhan Palace Square Cirebon, Dewi Supraba Group, from Dukuh Badag Village, Cibingbin District, Kuningan Regency (Source: Research Primary Data)

\section{Conclusion}

Sintren performing arts, which is one of folk art traditions at the border coastal of North Beach (coast) of West Java and Central Java (located precisely in the area of Indramayu, Cirebon, and Brebes), which has a uniqueness, beauty, and rarity and is considered as a traditional art which is laden with superstitious and acrobatic.

First, if it is traced from which of its origin of this art would be, there was no certainty. But it was more generally believed that the art had begun since the Dutch colonization era in 1930s. Even the word of Sintren itself has two possibilities of meanings: the first comes from the word "sinyo" which in Dutch means "youth" and "trennene" or exercise, and the second, derived from the word "sesantrian" means imitate students playing lais or Ubrug rudat using magics. This art was initially born when the habits of mothers and their 
children who were waiting for the husbands /fathers returned from fishing in the sea. Rather than sleeping in the afternoon, the fishermen who were living in the house, it was better for them to entertain themselves through creating Sintren game. However, if it is mythologically reviewed, Sintren art was born from a story that was pretty much adopted by some surrounding areas. The story was about a love story between Sulandono and Sulasih, whose love was not accepted by Sulandono's father (Ki Baurekso). Thanks to the magic power that Sulandono had assisted by his mother (Goddess Rantamsari) so that the couple could reunite their love eventhough they did not meet physically, but through the nature of magic, with using the dancers' media, their love can be united.

Second, the purpose of the Sinten performing arts was at first only habits of mothers and their children who were waiting for the husbands/fathers returned from fishing in the sea. Then it was evolved as the suburban folk art in certain villages and constantly played almost every afternoon and became an integral part of their lives. Sintren eventually turned into a sacred game including the rite for rain when it was drought. Even until now Sintren become a noble heritage with full of magic. Now this Sintren art is created as one of commercial interests that can become additional income for the Sintren promotors' lives. As a whole it can be noted that there are various types of sintren arts: (1) Sintren art which is deliberately held freely, without being stricked by time. Time here is usually associated with the season; Sintren is often performed in various types of wedding celebration ceremony, circumcision or just welcoming official guests of the localgovernment. (2) Sintren
Art which is held in a certain time. This type of Sintren is usually held at the time of drought, for 35 until 40 days. Sintren is believed to be a ritual art type of rain caller. This second type of Sintren is more performed in villages that still have not been touched by the progress of science and technology or society that still have simple lives.

Third, the stages of Sintren performing arts are as follows: (1) preparation phase: (a) Gamelan Instruments (once used: gembyung, tube, and bottles, but now used drums, guitar, flute, organ, and speakers or sound system, (b) Clothing (complete clothing for Sintren Comedian, and also for the Singers Kawih or Pesinden, (c) Kurungan/Chicken cage that is already decorated or prepared,(d) Dupa or aromatic sticks or other materials that are burned during whole performance takes place, (e) Sintren Dancers Penari is a young female girl; (f) Male Comedian Bodor who should be pure/virgin and slightly older than the Sintren; (g) Punduh/ Sintren handler; (h) Kawih/singer (approximately six people); (i) The Sintren songs show sung from start until finish.

(2) Performance Stages. In this case, the girl, the Sintren dancer, previously dresses casual "Cirebonan style", without wearing make- up, tightly ropped from neck to toe, with her full consciousness, she is guided by the handler enter into the cage, along with her, a package of costumes and cosmetics. In this staging, then the very young Sintren comes. By the time the cage is opened, she appears in different costume, and she is wearing thick make-up, black glasses, and is dressed in a sleeveless like the puppet costume, and in $3 / 4$ black pants, with a width belt made of a fabric that held sampur wrapped around the waist, decorated with 
jasmine strands on either side of the crown, and a black and white stockings, but still sits in a tied rope. The cage then closes again, with the strains of sintren songs that are increasingly wrenching the whole night. Soon as it vibrates and sways the chicken cage, and when the wrangler lifts it, the girl is no longer bound. Immediately she rises up and dances following to the beat of gamelan, with the choreography that is more like a mix between OndelOndel dance, the grip of traditional dance, with a variety of aesthetic movement. She is being finely possessed, by the Goddest widadari, that since the beginning of the show has got an invitation through the Dupa burning. Her consistent motion blends with the dance style inconsistencies. The sunglasses that actually functions as the dancer's eyes shut closed become her premium attractiveness.

(3) Closing stages. After the givers Balang of the free money have returned home, the Sintren princess bends over and the dance is closed by the Orok-orok song. When it is opened, the sintren girl is still wearing casual and plain dress, black glasses, and her hands tied, and unconscious. The handler reads the sacral words to wake her up. The performing ends with the eminent tune of Ulung-ulung song. With the end of the song, the Sintren dancer begins conscious again, and usually she blushes and then runs away from the audience.

Fourth, the values of the Sintren performing arts contribute to the history education that its philosophyical values can give contribution to history education. (1) Basically Sintren itself is the meaning of human life. The confinement is a symbol of the world and norms. Basically, human is locked up in this world. He should try hard to break free from the cage as visualized in sintren. When the world and norms confine, human has brain that can give strategy to break them, so he can liberate himself from the shackles of life. (2) Simple Gamelan in Sintren art represents that musical instruments not becomes the main thing. There are three premiums in Sintren performing arts: (1) the sinden, the singer is rhythmically monotonous and steady spells, becomes a leader for the whole show. The overall sound of the music, in essence merely accompaniment rhythm mantras chanted monotonously to facilitate the formation of the trance dancers sintren, (2) the mastermind, who is behind all the performances, which functions himself as a director, as a shaman or spiritualist or handler or pawing, and at the same time plays role as: (3) subject and object of all the dancers of Sintren performing arts itself, and recites the mantra or the spell of a handler blown on the knot of the dancers before they are plunged into the performance stage. The mantra songs are sung by the sinden, and their power can move the dancer. The angels are down from heaven, as a sacred object as a dancer. That is the reason why ancestry on the north coast of Java requires the dancer should be virgin. On the full moon in the night, the angel come down to the earth, the soul of a woman entering the virgin body who has never got periods yet. Sintren dancer plays both as subject and object in the show. It has been explained that humans when they are born, they are still pure and clean and wearing no clothes. The confinement or Kurungan symbolizes the world. The rope is considered as a bond between man and Allah SWT. The frankincense or Kemenyan symbolizes the senses because humans have a taste, creativity and initiative that are able to make the people become 
perfect beings. Thus the classical arts, such like the Sintren existence, can not be separated from the cultural values that contain moral messages; it is not only an art for entertaining, but there are certain messages that the people can learn from the play. However, the messages in the staging of Sintren are felt abstract so not everyone is able to catch their meanings.

Fifth, efforts to increase the history awareness in nurturing and developing the Sintren performing arts have been promoted through sintren regular performance and become an annual event in certain elementary school, especially in SD-I Lelea Indramayu, in order to preserve the local art and culture that can be maintained and preserved, so during this globalization era, the wisdom behind the local culture do not disappear and infiltrated by foreign cultures. The students are also able to sing the Sintren songs, because they also continue to learn the songs in the classroom. This efforts are done in order to rebirth the glory of Sintren art that should not become the concern of the local government including the community to develop the local culture treasures to become commodities as well as assets of the region. Even in other areas like in Kasepuhan Palace in Cirebon, the annual performances of traditional arts from various regions, including Sintren are always regularly performed.

Sintren performing arts which is one of the traditional folk art of coastal border of the North Coast (coast) of West Java and Central Java (precisely in the area of Indramayu, Cirebon, and Brebes), which has a uniqueness, beauty, and rarity is a traditional art which is laden with superstitious and acrobatic. The art will only be able to survive in this globalization era when people have a strong sense of history of art that remains to be loved and favored.

To feel love and fond of the arts, both community and regional government must simultaneously have a sense of belonging to the traditional arts. For the managers of Sintren art, they should innovately create and perform the more reform of sintren arts without losing the meaningfulness of tradional arts, even if performed in a simpler variety but do not lose the originality.

The wealth of traditional art should actually be maintained up to now, because the capability of maintainining and preserving has become a glory in an honor of the human mind in appreciating the history of its existence, and Sintren art is no exception. Sintren, in various versions, is an art that combines dance and theatrical skills spiced with acrobatic, even this art has influenced many Sintren artists and performers to develop further by incorporating elements of magic in it. Local government should be serious in their efforts to preserve the Sintren performing arts, because the history awareness of the community in developing traditional arts should also be increasing.

\section{REFERENCES}

Adam, A.V. (2001). "Pengendalian Sejarah". Dalam Daniel Dhakidae (Ed). 10oo Tahun Nusantara. Jakarta: Penerbit Kompas.

Creswell, J.W. (1994). Research Design Qualitative \& Quantitative Approach. London: Publications.

Hadisastro, S. (1999). Sintren Batang: Kesenian Pinggiran yang Terpinggirkan. Jakarta: Departemen Pendidikan dan Kebudayaan

Hakam, K. A. (2000). Pendidikan Nilai. Bandung: CV Maulana 
Kartodirdjo, S. (1992), Pendekatan Ilmu Sosial Dalam Metodologi Sejarah, Jakarta: PT. Gramedia Pustaka Utama.

Keputusan Menteri Pendidikan dan Kebudayaan tanggal 13 Juli 1987 No. 014. Ga/U/87, Jakarta: Departemen Pendidikan dan Kebudayaan RI.

Miles, M., dan Huberman, M. (1992). Analisis Data Kualitatif: Buku Sumber tentang Metode-metode Baru. Translated by Tjetjep Rohendi Rohidi. Jakarta: UI Press.

Mundardjito. (1986). "Hakikat Local Genius dan Hakikat Data Arkeologi”. Dalam Ayatrohaedi. Kepribadian Budaya Bangsa (Local Genius), Jakarta: Pustaka Jaya, (39-45).

Namier, L.B. (1957). The Structure of Politics at the Accession of George III. Basingtoke: Macmillan.

Niebuhr, R. (1949). Faith and History. New York: Scribner.

Purnama, Y, dkk,. (2004). Budaya Tradisional pada Masyarakat Indramayu. Bandung: Kementerian Kebudayaan dan Pariwisata, Balai Kajian Sejarah dan Nilai Tradisional Bandung.

Saunders, M. (1982). Multicultural Teaching: Aguide for the Classroom, London: McGraw-Hill Company.

Sedyawati, E (1986). "Local Genius dalam kesenian Indonesia". Dalam Ayatrohaedi. Kepribadian Budaya Bangsa (Local Genius). Jakarta: Pustaka Jaya, (186-192).

Simbolon, P. T (2000). "Indonesia Memasuki Milenium Ketiga", dalam 1000 Tahun Nusantara. Jakarta: PT Kompas Media Nusantara.

Sindhunata. (2000). "Demitologisasi Persatuan Nasional" dalam 1000 Tahun Nusantara. Jakarta: PT Kompas Media Nusantara.
Sjamsuddin, H. (1996). Metodologi Sejarah. Jakarta: Depdikbud, Proyek Pendidikan Tenaga Akademik.

Spradley, J. (1997). Metode Etnografi. Penerjemah Misbah Zulfa Elizabeth. Yogyakarta: Tiara Wacana.

Surjomihardjo, A. dan Abdullah T. (1998). Ilmu Sejarah dan Historiografi Arah dan Perspektif. Jakarta: PT Gramedia.

Soebadio, H. (1986). Kepribadian Budaya Bangsa. Dalam Ayatrohaedi, Kepribadian Budaya Bangsa (Local Genius). Jakarta: Pustaka Jaya, halaman 18-25.

Soedjatmoko. (1995). "Sejarawan Indonesia dan Zamannya," dalam Historiografi Indonesia: Sebuah Pengantar. Jakarta.

Soedjatmoko. (1985). Etika Pembebasan, Pilihan Karangan Tentang Agama, Kebudayaan, Sosial dan Ilmu Pengetahuan. Jakarta: LP3ES.

Soedjatmoko. (1976). "Kesadaran Sejarah dan Pembangunan", in Prisma No.7. Tahun V, Jakarta. LP3ES, hal. 9-16.

Sujatmiko, G. (1999). Perbedaan Nasionalisme Generasi Tua dan Muda. Makalah Seminar Nasional di Universitas Indonesia (Tidak dipublikasikan)

Triardianto dan Suwardiman. (2002). Indonesia dalam Krisis. Jakarta: Penerbit Kompas.

Umar, K.(1981).Seni,Tradisi, Masyarakat. Jakarta: Sinar Harapan.

Yudistira, D. W. (2007). Sintren. Jakarta: Grasindo.

Wales, H.G. Quartrich (1948) "The Making of Greater India: A Study in South-East Asia Culture Change", Journal of Royal Asiatic Society, (2-32). 